\title{
The Characteristics of Undernutrition in Toddlers
}

\author{
$1^{\text {st }}$ Sudiyah \\ Faculty of Health Science \\ Universitas Aisyiyah Yogyakarta \\ Yogyakarta, Indonesia
}

\author{
$* 2^{\text {nd }}$ Luluk Rosida \\ Faculty of Health Science \\ Universitas Aisyiyah Yogyakarta \\ Yogyakarta, Indonesia \\ rosidalulu@gmail.com
}

\begin{abstract}
Toddlerhood is an important period in the process of human growth and development. The period of growth and development at this age takes place quickly and will never be repeated, that's why it is often called the golden age or golden period. Lack of nutrients absorbed by the body results in disease, because nutrition plays an important role in the body's immunity. The purpose of this study was to determine the characteristics of toddler suffering from malnutrition in Tepusen Public Health Center, Kaloran District, Temanggung Regency in 2019. The study design used descriptive research with a retrospective approach. The population in this study were 60 people, the sampling technique used a total sampling technique with a total sample of 60 respondents who met the inclusion criteria. The research instrument used secondary data. Data were analyzed using descriptive statistics with the results of toddlers suffering from malnutrition at the age of $1-<3$ years 31 respondents $(48.33 \%)$, did not get exclusive breastfeeding 48 respondents $(80 \%)$, normal birth weight 58 respondents $(96.66 \%)$, complete immunization 58 respondents $(96.66 \%)$, birth spacing $\geqslant 2$ years 58 respondents $(96.66 \%)$, and toddlers get vitamin $A$ as many as 60 respondents $(100 \%)$. Based on the results of this study, it is expected that health workers and the public will pay more attention to the nutritional needs of toddlers.
\end{abstract}

Keywords- Characteristics of Toddler, Malnutrition, Toddlers

\section{INTRODUCTION}

Toddlerhood is an important period in the process of human growth and development. The period of growth and development at this age is a period that takes place quickly and will never be repeated, because it is often called the golden age. Every toddler needs nutrition with a balanced menu and the right portion, not excessive and adjusted to the needs. If the provision of nutrition in toddlers is not good in terms of quality or quantity, the growth and development of toddlers will run slowly. The lack of nutrients absorbed by the body results in susceptible to disease because nutrition plays an important role on immunity. Nutrition does not only affect the health of the body, but also affects intelligence. If the nutrients needed by the brain are not fulfilled, the brain will get influenced so it doesn't develop [1]

The prevalence of malnutrition (body weight according to age) in toddlers in the world, recorded 101 million toddlers in the world suffer from malnutrition, toddlers including malnutrition have a higher risk of death compared to toddlers with good nutrition (UNICEF, 2013). Basic Health Research (2013) in Indonesia is $19.6 \%$ consisting of $5.7 \%$ malnutrition and $13.9 \%$ undernutrition. The national prevalence rate in 2007 (18.4\%) compared to in 2010 (17, $9 \%$ ) seen an increase. Changes mainly in the prevalence of malnutrition, namely $5.4 \%$ in $2007,4.9 \%$ in 2010 and $5.7 \%$ in 2013. This shows that an increase in the amount of undernutrition and malnutrition every year from 2010 to 2013.

To achieve the 2015 MDGs target of $15.5 \%$, the prevalence of malnutrition and undernutrition nationally must be reduced by $4.1 \%$ in the period 2013 to 2015 , while the prevalence of undernutrition of toddlers $13.0 \%$ in 2010 to $11,9 \%$ in 2015 (Bappenas, 2012). Nutrition Status Monitoring (PSG) 2017 results obtained as many as 3.8\% of toddlers have malnutrition status and $14.0 \%$ of toddlers have undernourished status. The percentage of underweight / severe malnutrition in toddlers' group (17.8\%) was higher than the underweight group (14.8\%). In Central Java province the prevalence of malnutrition children was $2.7 \%$ while the prevalence of malnutrition children was $10.6 \%$. Temanggung Regency the percentage of underweight toddlers is $12.7 \%$ (Kemenkes RI 2018). Based on the nutrition data report of Tepusan Public Healt Center in 2018 there were 60 toddlers with undernourished of 775 toddlers $(6,5 \%)$ in 6 work place of Tepusan Public Health Centre.

The risk factors that can cause undernutrition originating from individuals, namely age, this is in accordance with Nina Dwi Lestari's research in 2016 which shows that toddlers aged 1-3 years have a greater chance of experiencing good nutrition. Whereas toddlers aged 3-5 years have greater chance of experiencing malnutrition. Other risk factors such as completeness of immunization according to a study conducted by Novitasari in 2012 showed that there was a correlation between the completeness of immunization in infants and the incidence of malnutrition. Malnutrition status is also influenced by a history of birth weight and a history of exclusive breastfeeding, such as research conducted by Rasyid, Mayulu dan Kandou 2015 in Gambesi Public Health Center in Ternate city showed that there was a significant correlation between birth weight history and toddlers' nutritional status which stated that toddlers history with normal birth weight had a greater chance of getting good nutrition compared to toddlers who had low birth weight and showed that there was correlation between exclusive breastfeeding and nutritional status of toddlers which explains that toddlers who do not get exclusive breastfeeding experience malnutrition as many as $63.8 \%$. Research conducted by Nurjanah and Septiani in 2013, malnutrition is also influenced by birth spacing which shows that there is a correlation between birth spacing and status toddler nutrition, namely birth spacing $>2$ years has a greater chance of 
experiencing normal nutrition than birth spacing $<2$ years. Adam (2012) also explains that another risk factor that can cause malnutrition is vitamin $\mathrm{A}$, where toddlers who get vitamin A capsules have less chance of undernutrition than not getting a vitamin A capsule.

\section{ReSEARCh Method}

This study used descriptive research with a retrospective approach. The population were 60 toddlers. The number of samples in the study was 60 toddlers, with a total sampling technique. Data was collected using a master documentation table containing the respondent's identity, age, birth distance, immunization status, birth weight, vitamin A status and descriptive analysis.

\section{RESUlt AND DISCUSSION}

From the results of the study obtained the characteristics of respondents.

TABLE I. FREQUENCY DISTRIBUTION OF RESPONDENT CHARACTERISTICS

\begin{tabular}{|c|c|c|}
\hline \multirow{2}{*}{ Toddler Characteristics } & \multicolumn{2}{|c|}{ Frequency } \\
\hline & $\mathrm{N}$ & $\%$ \\
\hline \multicolumn{3}{|l|}{ Age } \\
\hline $1-<3$ years & 31 & 51.66 \\
\hline $3-5$ years old & 29 & 48.33 \\
\hline \multicolumn{3}{|l|}{ Exclusive breastfeeding } \\
\hline Exclusive breastfeeding & 48 & 80 \\
\hline No Exclusive breastfeeding & 12 & 20 \\
\hline \multicolumn{3}{|l|}{ Birth weight } \\
\hline Less & 2 & 3.33 \\
\hline Normal & 58 & 96.66 \\
\hline More & 0 & 0 \\
\hline \multicolumn{3}{|l|}{ Immunization } \\
\hline Complete & 58 & 96.66 \\
\hline Incomplete & 2 & 20 \\
\hline \multicolumn{3}{|l|}{ Birth Distance } \\
\hline$>2$ years & 58 & 96.66 \\
\hline$<2$ years & 2 & 3.33 \\
\hline \multicolumn{3}{|l|}{ Giving Vit A } \\
\hline Get & 60 & 100 \\
\hline Do not get & 0 & 0 \\
\hline
\end{tabular}

Based on table 4.1 it can be seen that the age of toddlers suffering from malnutrition is mostly at age $1-<3$ years totaling 31 toddlers $(51.66 \%)$. In the history of exclusive breastfeeding, most respondents received exclusive breastfeeding, as many as 48 infants $(80 \%)$. Most of the normal weight babies born to more than 2500 grams were 58 toddlers $(96.66 \%)$. Most toddlers who experience malnutrition have received full immunization as many as 58 children $(96.66 \%)$. seen from the distance of toddlers' birth who experience nutrition most of them were $<2$ years as many as 58 toddlers $(96.66 \%)$. Toddlers who experience undernutrition all get vitamin A which is 60 toddlers (100\%).

The risk factors that can cause malnutrition originating from individuals, namely age. Based on the results of the study known that at the age of $1-<3$ years toddlers who suffer from malnutrition as many as 31 toddlers $(51.66 \%)$ and 3-5 years of age are 29 toddlers $(48.33 \%)$. As a child gets older, the child will become an active consumer, they can already choose the foods they like such as buying any food without paying attention to the type of food chosen and the cleanliness of the food. Less hygiene food can cause toddlers to get sick easily, if toddlers get sick there can be a decrease in appetite and it can result in a lack of nutrients that enter the body[2].

At this age toddlers also start being active to play with their peers so that they need adequate nutrition, if the nutrients that enter the body are not balanced with toddler's activities, this will also affect the nutritional status of children and can cause malnutrition. This is in line with research conducted by Kuntari, Jamil and Kurniati in 2013 with the title "Malnutrition Risk Factors in Toddlers in Kasihan District, Bantul" showing that toddlers aged 1-3 years have a greater chance of experiencing malnutrition compared to toddlers aged 3-5 years. As age increase, children are vulnerable to experiencing malnutrition, parental attention to food quality also decreases, either main food or snacks (distraction) because children can begin to choose or buy their own food they want, while the physical activity of children of this age group is quite high [3]

In this study data collection was carried out at the age of 1 year and above. At this age, toddlers are cared for by grandmothers and left to work so they are given less nutritious food. The food provided is in the form of junk food / snacks that do not pay attention to the nutritional content. Food consumed does not match the nutritional needs of children. Toddlers should consume foods with balanced nutritional composition so that nutritional needs are fulfilled. The results showed that the frequency distribution of toddlers with severe malnutrition had received exclusive breastfeeding at 48 toddlers $(80 \%)$ while 12 non-exclusively breastfed $(20 \%)$. Toddlers who are not given exclusive breastfeeding are very susceptible to malnutrition and make it easier to be infected infectious diseases due to lack of immunity obtained from exclusive breastfeeding. This is a quite serious problem that exclusive breastfeeding patterns and poor complementary feeding are one of the causes of growth disorders in infants. breastfeeding contains a variety of nutrients in complete quantities as needed, antibodies for the body's defense from various infectious diseases. Until the age of six months the baby's nutritional needs can be met by the baby, so the baby does not need to be given food or drinks other than breast milk [4].

Based on the World Health Organization (WHO) in 2009 stated about $15 \%$ of the total cases of toddler mortality in developing countries caused by non-exclusive breastfeeding. Exclusive breastfeeding is one of the efforts in improving nutrition in children which will ultimately have an impact on the quality of human resources. Breastmilk affects the incidence of malnutrition because breast milk contains antibodies so that infants who are not given exclusive breastfeeding will be susceptible to disease and will play a direct role in the nutritional status of infants [5].

Lack of breastfeeding to infants can affect the incidence of malnutrition, this happens because in breast milk contains antibodies that can protect babies from various infectious and allergic diseases so that toddlers who are not given exclusive breastfeeding will be susceptible to disease and will play a direct role in the nutritional status of toddlers. 
In this study more respondents with a history of exclusive breastfeeding experienced malnutrition due to data collection was done at the age of 1 year and above. At this age, toddlers are cared for by grandmothers and left to work so they are given less nutritious food. The food provided is in the form of junk food / snacks that do not pay attention to the nutritional content. Food consumed does not match the nutritional needs of children. Toddlers should consume foods with balanced nutritional composition so that nutritional needs are fulfilled.

Another factor could be from parenting for their children because at baby's age all the food received by the baby still depends on what is given by parents in this case providing inappropriate complementary feeding (MP-ASI) that is late in giving complementary feeding (MP-ASI). MP-ASI is food or drink containing nutrients given to more than 6 months old children to meet nutritional needs other than breast milk. This is because breast milk is only able to meet two-thirds of the needs of infants at the age of 6-9 months, and at 9-12 months of age fulfill half of baby's needs. So, if the baby does not get nutrition (MP-ASI) with the frequency, type, amount and method of feeding that is lacking, it can affect the nutritional status. This is in line with Lestari, Mahaputri U., et al., research in 2012 concerning the correlation between feeding MP-ASI with nutritional status of children aged 1-3 years stated that there was a correlation between giving MP-ASI with nutritional status of toddlers in this case the nutritional status was not only influenced by the type of MP-ASI, but also by the frequency and good way of feeding [6].

Based on the results of the study showed that there are 2 toddlers $(3.33 \%)$ who have a history of low birth weight $(<2500$ grams) who are suffering from malnutrition. According to the study of Uki Ningsih, et al (2016) stated that LBW has a 3.34 times greater risk of experiencing undernourished status compared to toddlers who are not LBW. In this study there were 2 girls $(3.33 \%)$ who had a history of low birth weight $(<2500$ grams). LBW infants indicate a lack of fulfillment of nutritional needs and a higher risk of infant death, chronic illness in adulthood, mental delays and slow growth due to malnutrition that risks causing infants to suffer from PEM. In LBW antibodies are less than perfect so they are more susceptible to disease. This disease causes toddlers to lack appetite so that the intake of food that enters the body is reduced and can cause undernutrition and can even cause malnutrition.

This is also in line with research conducted by Kuntari, Jamil, and Kurniati in 2013 which found children with birth weight equal to or more than 2500 grams at risk of one-fifth less to experience malnutrition compared to children with birth weight less than 2500 grams. This study was also supported by the results of research from Nova $H$. Kapantow, et al in 2016 with the title the correlation Between Child Birth Weight and Giving Exclusive Breastfeeding with Nutritional Status in Children Age 24-59 Months in Ranotana Weru Public Health Center in Manado City with the Fisher Exact test results, obtained a value of $\rho$ of 0.421 because the value of $\rho>0.05$ then there is no statistical correlation between birth weight and nutritional status based on weight / U.
The results showed that most of the immunizations were complete $(96.66 \%)$ but there were still toddlers who did not carry out complete immunizations there were 2 toddlers $(3.33 \%)$. Immunization is one of the efforts to make inexpensive health investments in preventing diseases. One of the programs that became the priority of health development in 2015-2019 was improving the nutritional status of toddlers. One effort made in intervening in nutritional status in infants is with a complete basic immunization (Kemenkes RI 2016). This study is in line with research conducted by Kasim, et al (2019), there is no meaningful correlation between the history of immunization and nutritional status. Toddlers who have received complete immunization are expected to avoid infectious diseases which are the most common disease complications in toddlers. This will certainly affect the nutritional status of toddlers, toddlers whose immunizations are complete will rarely get sick so that the nutrients provided can be well absorbed and better nutrition.[7].

In this study most of the immunizations are complete but there are still toddlers suffering from malnutrition, from the researchers' assumption that there may be other factors such as poor environmental sanitation, this will cause the spread of disease. Even though the immunization is complete, the clean and healthy living behavior that is lacking is still susceptible to an infectious disease, this infectious disease can cause a toddler to lose his appetite and consequently a toddler may experience malnutrition. But there are 2 toddlers $(3.33 \%)$ who do not get complete immunizations, where immunization is very important for the child's immune system. Toddlers who are fully immunized will be healthier and rarely sick so that their growth and development is appropriate. Because at the age of this toddler growth and development is very fast so that if a toddler experiences pain it will certainly affect the nutrients intake less due to a decrease in appetite and can affect the nutritional status of toddlers. This is in accordance with research conducted by Ameliat in 2014 which shows that toddlers who are malnourished are mostly incomplete immunization status, while for the most good nutritional status in toddlers with complete immunization status.

The results showed that almost all toddlers 58 toddlers (96.66\%) the closest birth distance to their siblings is $\geqslant 2$ years. But there are 2 toddlers whose birth space $<2$ years so in this study to determine the birth spacing can be seen from the age of the current toddler, if he is more than 24 months or approaching 24 months and all mothers of 2 toddlers are not currently pregnant so that included into the category $\geqslant 2$ years. The distance between one baby's birth and the next pregnancy is at least 2 years so the mother can pay special attention during this time. There are 2 toddlers who experience malnutrition, namely the birth distance with their closest siblings $<2$ years. The Demographic and Health Survey, states that children born 2-5 years after the birth of a previous child, have the possibility of a healthy life 2,5 times higher than those whose space less than 2 years, the safe distance for pregnancy is 2-5 years. The distance between pregnancy or birth that is close $(<2$ years) can also neglect the first child physically and psychologically, which can cause racial jealousy due to unpreparedness to share the love of his parents[5]. 
Seen from the data the birth distance with the closest sibling is already good, that is $\geqslant 2$ years, but there are still many who experience undernutrition due to lack of knowledge and awareness of mothers about health care lack of mother's knowledge about nutrition causes reduced food diversity (Septikasari \& Septiyaningsih, 2016). Research conducted by Rakhmawati (2013) states that the mother's knowledge and attitude factors in feeding child very related to the undernutrition status of toddlers. Mothers who have got full time work no more can give full attention to their toddlers, moreover to take care of them. Although not all working mothers do not take care of their children, the busyness and workload that they bear can cause the mother's lack of attention in preparing dishes that are suitable for her toddler. Nutritious food intake can also be influenced by family economic factors. The majority of respondents' occupational backgrounds in Tepusen Public health Care are farmers and laborers. Family economic factors can have an impact on low purchasing power in this case food for the family. If the quality and quantity of food consumption cannot be fulfilled properly, it can cause malnutrition in toddlers. This is in lline with research conducted by Novitasari (2012), which states that there is a meaningful correlation between family socioeconomic factors with the incidence of malnutrition in toddlers[2].

Based on statistical records that the safe birth distance between one child and another is $>2$ years. At this distance the mother will have a healthy baby and survive while passing through the pregnancy process (Agudelo, 2007). This is in accordance with research conducted by Nurjanah and Septiani in 2013 which showed that the correlation between birth space and the nutritional status of toddlers is birth space $>2$ years has a greater chance of experiencing normal nutrition than birth space $<2$ years. Based on the results of the study, it is known that all children who experience malnutrition turn out to all get vitamin A which is 60 toddlers $(100 \%)$. Efforts to overcome micronutrients through providing vitamins and strengthening the application of cases of malnutrition and malnutrition in health facilities. (RI Ministry of Health, 2012)

Soeparmanto in Putri in 2008 said that the toddler period was a "window of opportunity" in which the toddlers needed a balanced nutritional intake of quality and quantity for optimal weight and height. Toddlers who experience malnutrition usually also suffer from vitamin deficiencies, one of which is vitamin A. Research in Kenya shows that children who are not given vitamin A have a $75 \%$ risk of being underweight compared to those given vitamin A. Based on research conducted by Hanifa (2013) on the Correlation between Giving Vitamin A and baby under 2 years Nutritional Status in Rejosari, Madiun, there is a correlation between the provision of vitamin A and under baby under 2 years nutritional status. In this study shows that all toddlers have received vitamin A $(100 \%)$ so that the government program has been carried out twice a year, namely in February and August. The function of vitamin A is for the process of formation and growth of red blood cells, lymphocyte cells, so play a role in the immune system.[2].
However, even though vitamin A is already $100 \%$, there are still many toddlers suffering from malnutrition. From the research assumptions the cause of the discrepancy with previous studies could be due to the lack of nutritional conditions arising from the wrong diet or the child is experiencing pain that affects his weight and so are not given adequate nutrition. There are still mothers who think that children eat a lot is enough but do not pay attention to the nutritional balance of these foods. Food that is good for children is not enough, but also must be considered from the portion of nutrition. good food is one that meets balanced nutrition where all the intake of children's needs is in it.

\section{CONCLUSION}

Toddlers who suffer from malnutrition based on age at the age of $1-<3$ years, as many as 31 respondents $(51.66 \%)$. Most of the toddlers suffering from undernutrition suffer from exclusive breastfeeding for 6 months as many as 48 respondents $(80 \%)$. most of those who suffer from malnutrition have a history of normal birth weight of 58 respondents (96.66\%). Toddlers who experience undernutrition are mostly complete immunization that is as many as 58 respondents $(96.66 \%)$. birth distance with the closest sibling is highest at birth interval $\geqslant 2$ years with a total of 58 respondents $(96.66 \%)$. Toddlers who suffer from malnutrition entirely have received vitamin A which is 60 respondents $(100 \%)$

\section{ACKNOWLEDGMENT}

The author would like to thank to all parties who support this research and to 'Aisyiyah University of Yogyakarta. The author also expressed gratitude to the team who helped prepare the set-up of equipment and assist retrieval of data.

\section{REFERENCES}

[1] E. E. Sibagariang, GIZI Dalam Kesehatan Reproduksi. 2010.

[2] D. Rasyid R., Mayulu, N. and G. . Kandou, "Hubungan Karakteristik Balita, Penyakit Infeksi Dengan Status Gizi Pada Anak Balita Di Wilayah Kerja Puskesmas Gambesi Kota Ternate," J. Kesehat. MasyarakatUniversitas SamRatulangi.

[3] T. D. Nurjanah, Nunung dan Septiani, "Hubungan Jarak Kelahiran Dan Jumlah Balita Dengan Status Gizi Di Rw 07 Wilayah Kerja Puskesmas Cijerah Kota Bandung," J. Keperawatan Anak, 2013.

[4] A. H. Agus Hendra AL-Rahmad, Ampera Miko, "KAJIAN STUNTING PADA ANAK BALITA DITINJAU DARI PEMBERIAN ASI EKSKLUSIF, MP-ASI, STATUS IMUNISASI DAN KARAKTERISTIK KELUARGA DI KOTA BANDA ACEH," J. Kesehat. Ilm. Nasuwakes, 2013.

[5] S. P, "Gambaran Karakteristik Ibu Dan Anak Terhadap Kejadian Gizi Kurang Pada Anak Balita Di Desa Sukawati Gianyar Tahun 2014,” Intisari Sains Medis, 2014.

[6] et al. Lestari, Mahaputri U., "Hubungan Pemberian Makanan Pendamping Asi (MP-ASI) dengan Status Gizi Anak Usia 1-3 Tahun di Kota Padang Tahun 2012," J. Univ. Andalas, 2012.

[7] L. Dian, "Hubungan Pendidikan dan Pekerjaan Orangtua serta Pola Asuh dengan Status Gizi Balita di Kota Dan Kabupaten Tangerang, Banten,”J. Kesehat. Masy., 2011. 